\title{
メタンスルフィン酸の生成に基づくヒドロキシル ラジカルの高速液体クロマトグラフ間接定量
}

\author{
蒲生 啓司 ${ }^{\mathbb{B}}$, 坂本 真紀 $^{*}$
}

(1994 年4月1日受理)

\begin{abstract}
ヒドロキシルラジカルがジメチルスルホキシドとの反応によって生成するメタンスルフィン酸に着目 し，これとジアゾニウム填のカップリング反応により生成するジアゾスルホンを溶媒抽出後, 逆相分配 HPLCにより分離・検出するヒドロキシルラジカル間接定量法を検討した。メタンスルフィン酸ナト リウムを槽準試料として，ジアゾスルホン検出のための最適条件を検討した結果， $0.5 \sim 10 \times 10^{-3} \mathrm{mM}$ の濃度範井でジアゾスルホンのピーク面積值との間に直線関係が得られ，検出下限は $0.25 \times 10^{-3} \mathrm{mM}$ であった．本法を，Fenton 反応によるヒドロキシルラジカルの発生系に応用した結果，過酸化水素濃 度 $10 \sim 200 \times 10^{-3} \mathrm{mM}$ の範囲に打いて, メタンスルフィン酸由来のジアゾスルホンのピーク面積值と の間に良好な植線関係が喼められ，これにより， $80 \times 10^{-3} \mathrm{mM}$ の過酸化水素から $8.8 \times 10^{-3} \mathrm{mM}$ の ドロキシルラジカルの発生が確認された。
\end{abstract}

\section{1 緒言}

ヒドロキシルラジカル (OH ラジカル) は, スーパー オキシド陰イオン, 過酸化水素, 及び一重項酸素と共に 活性酸素種として知られ, 生体内における代謝, 殺菌, 生理活性物質の産生に関与する一方で, DNA 損傷や発 がん性物質の水酸化による発がん, あるいは各種炎症の 発現に大きくかかわる化学種として注目されてき $た^{12)}$. $\mathrm{OH}$ ラジカルは, 過酸化水素やスーパーオキシ ド陰イオンから生ずる最終の活性型酸素であると言わ れ, 生体内成分に対する反忘性も高く, 短寿命であり, 定量性はもちろん, 特異性や感度的に優れる測定法はい まだ確立されていない。

すなわち, 吸光光度法や HPLC によるものには, フ エノール類の水酸化反忘に基づき, 生成するカテコ一 ル ${ }^{3)}$ やヒドロキノン ${ }^{4)}$ を検什する方法を始めとして, 数 多くの測定法が知られているが，いずれも一長一短があ る. 一方, ジメチルスルホキシド (DMSO) を用いる $\mathrm{OH}$ ラジカルの测定法として, Russel 反応により生成 するホルムアルデヒドの検出方法が報告されている が5), ホルムアルデヒドがメチルラジカルに由来するた め, その生成量が不正確であるうえ, 検出感度が低いな どの問題が残されている.

* 高知大学教育学部: 780 高知県高知市曙町 2-5-1
最近 Steiner らは, 同じ Russel 反応において生成す るメタンスルフィン酸に着目し，これとジアゾニウム塩 とのカップリング反応により生成するジアゾスルホンを 溶媒抽出後, 比色定量する方法を報告している ${ }^{6)}$ ここの 方法は反応の選択性に優れ，高感度検出も期待できる が，吸光光度法では反応による副生成物や系内のきょう 雑物之の分離がなされないため, 定量性には疑問が残さ れている. そこで著者らは，ジアゾスルホンの検出に逆 相系 HPLC を用いる, OH ラジカルの間接定量法の確 立を図った。

ところで, 標品としての $\mathrm{OH}$ ラジカルが存在しない 限り, OH ラジカル発生のモデル系とその発生量につい ては常に問題となる点であるが, 少なくともスピントラ ップ法による ESR スペクトル上, OH ラジカルの発生 が確認されている反応系をモデル系として用いることは 妥当である. 従って本研究においても, それの確認を行 った Fenton 反応及び過酸化水素の UV 照射を OH ラ ジカル生成のモデル系として選んだ. 次いで,これらの DMSO 共存下での反応を検討し, 生成するメタンスル フィン酸をジアゾスルホンとして HPLC 検出し, その 定量值より $\mathrm{OH}$ ラジカルの存在量を推定することとし た.

なお，反応には Babbs らの方法”に準じて，最もモル 吸光係数の高いジアゾスルホンが得られるファストブ ルーBB 塩をジアゾニウム塩として用いることとした. 


\section{2 実験}

\section{$2 \cdot 1$ 試 薬}

メタンスルフィン酸ナトリウムは Fairfield Chemical 製，ファストブルーBB 塩（4-ベンゾイルアミノ-2,5-ジ エトキシベンゼンジアゾニウムクロリド) は Sigma 製，DMSO 及び硫酸鉄(II) は和光純薬製を用いた。過 酸化水素は三菱瓦斯化学製を過マンガン酸カリウムで滴 症後標定して用いた。 その他の溶媒及び試薬は市販特級 品を用いた。

\section{$2 \cdot 2$ 装置及び HPLC 条件}

HPLC 装置として, 送液ポンプ LC-10AD 型, 紫外 可視吸光光度検出器 SPD-10AV 型, 力ラム恒温槽 CTO-6A 型，記録計 C-R4A 型（いずれも島津製作所 製)，及び Rheodyne 製サンプルインジェクター 7125 型を用いた．光反応装置として低圧水銀ランプ(アリオ ン製）を設置した内部照射型反応装置（シゲミスタン ダード商事製) を用いた。

ジアゾスルホンの分離・検出については, 逆相分配 モード用の ODS カラム（島津テクノリサーチ製 STRODSII $5 \mu \mathrm{m}$, 内径 $4.6 \mathrm{~mm}$, 長さ $250 \mathrm{~mm}$ ) を, カラム 温度 $40^{\circ} \mathrm{C}$ で用いた。移動相としてアセトニトリルと水 との混合液 $(8: 2, \mathrm{v} / \mathrm{v})$ を, 流量 $0.7 \mathrm{ml} / \mathrm{min}$ で用い た。検出波長は $420 \mathrm{~nm}$ とし, 反応溶液の $5 \mu \mathrm{l}$ をカ ムに注入した。

\section{$2 \cdot 3$ ジアゾスルホンの調製}

標品としてのジアゾスルホンは, $50 \mathrm{mM}$ メタンスル フィン酸ナトリウム $5 \mathrm{ml}$ に, $50 \mathrm{mM}$ ファストブルー $\mathrm{BB}$ 塩水溶液 $5 \mathrm{ml}$ を加え，暗所室温において 10 分間反 応させ, 生成したジアゾスルホンを水で洗浄しながら吸 引沃過し, 窒素気流下で乾燥したものを標品として用い た。

\section{$2 \cdot 4$ 定量操作}

標品としてのメタンスルフィン酸ナトリウム水溶液, 又はメタンスルフィン酸を含む試料 $0.5 \mathrm{ml}$ に, $2 \mathrm{M}$ 硫 酸を $0.1 \mathrm{ml}$ 加えて硫酸酸性として, 更にブタノール 1.0 $\mathrm{ml}$ を加えて十分に振り混ぜ，ブタノール相 $0.4 \mathrm{ml}$ を分 取した。ここに $500 \mathrm{mM}$ 酢酸ナトリウム水溶液 $0.5 \mathrm{ml}$ を加えてメタンスルフィン酸をナトリウム塩として転溶 させ，その水相 $0.4 \mathrm{ml}$ を分取し， $10 \mathrm{mM}$ ファストブ ルー BB 塩 $0.5 \mathrm{ml}$ を加えてジアゾスルホンを生成さ せ，最後にクロロホルム $0.5 \mathrm{ml}$ を加えてジアゾスルホ

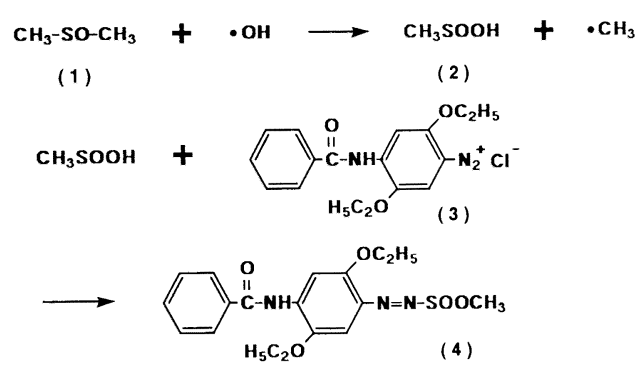

Fig. 1 General scheme for the formation of methanesulfinic acid and diazosulfone.

(1) DMSO (dimethyl sulfoxide); (2) methanesulfinic acid; (3) diazonium salt; (4) diazosulfone.

ンを抽出し，HPLG 用の試料とした。

\section{$2 \cdot 5 \mathrm{OH}$ ラジカルの発生系及びメタンスルフィン酸 の生成}

Fenton 反応における $\mathrm{OH}$ ラジカルの発生とメタンス ルフィン酸の生成: 一定濃度に調製した過酸化水素を含 む $100 \mathrm{mM}$ の DMSO 水溶液 $1 \mathrm{ml}$ を, 硫酸鉄を含む $100 \mathrm{mM}$ の DMSO 水浴液 $1 \mathrm{ml}$ 中に添加し, 生成した メタンスルフィン酸を定量した。

過酸化水素の UV 照射における $\mathrm{OH}$ ラジカルの発生 とメタンスルフィン酸の生成: 過酸化水素を含む 100 $\mathrm{mM}$ の DMSO 水溶液に, 低压水銀灯を用いて一定時間 光照射し，生成したメタンスルフィン酸を定量した。

\section{3 結果及び考察}

本研究における $\mathrm{OH}$ ラジカルによるメタンスルフィ ン酸の生成，それに続くジアゾニウム塩とのジアゾスル ホンの生成反応を Fig. 1に要約した。すなわち，既知 濃度のメタンスルフィン酸（ナトリウム塩）標品を用 い, それから得られるジアゾスルホンを HPLC 上の基 準クロマトグラムとした。…万， DMSO から OH ラジ カルによって生成するメタンスルフィン酸を测定するこ とによって，系内に発生した $\mathrm{OH}$ ラジカルの濃度を間 接的に定量することができると考え，初めにジアゾスル ホンの吸光光度検出による逆相系 HPLC と, 検出下限 について検討した。

メタンスルフィン酸は，それ主身ではジアゾニウム塩 との反応収率が低いため，一度ナトリウム盍等に導く必 要がある. 従って, 既知濃度のメタンスルフィン酸ナト リウムから得られるジアゾスルホンを基準クロマトグラ ムとして, 以下 $\mathrm{OH}$ ラジカル起量のための最適条件を 


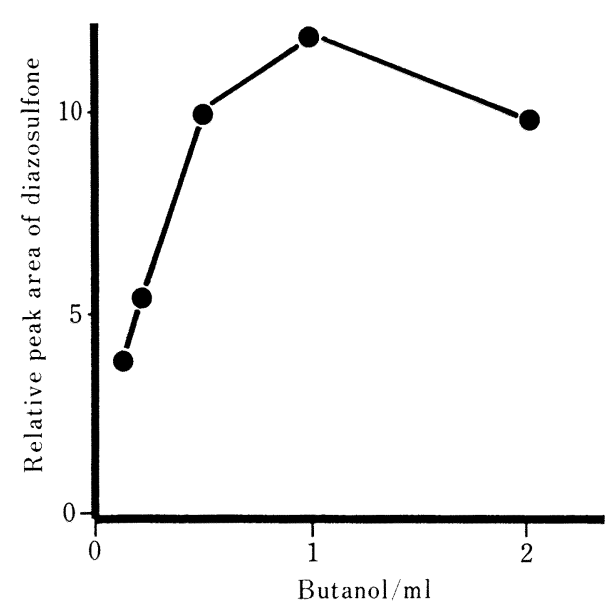

Fig. 2 Effect of the extraction volume of butanol on the formation of methanesulfinic acid.

Reaction conditions: $1 \mathrm{mM}$ sodium methanesulfinate $(0.5 \mathrm{ml}), 10 \mathrm{mM}$ fast blue $\mathrm{BB}$ salt $(0.5 \mathrm{ml})$, chloroform $(0.5 \mathrm{ml})$. HPLC conditions: column, STRODS II $(4.6 \mathrm{~mm}$ i.d. $\times 250 \mathrm{~mm})$; mobile phase, acetonitrile/water $(8: 2)$; flow rate, $0.7 \mathrm{ml} / \mathrm{min}$; column temperature, $40^{\circ} \mathrm{C}$; detection, $420 \mathrm{~nm}$

検討した。

なお，Babbs らの報告7では，ジアゾスルホンの吸光 光度定量法の際，抽出に用いる有機溶媒としてトルエ ンーブタノール混合液を用いているが, 抽出効率とクロ マトグラムトのきょう雑成分を比較した結果からは，ク ロロホルムが最も高い抽出効率を示し, きょう雑成分も 少なかったので, 本実験ではクロロホルムを抽出溶媒之 して用いた。

実武料に則した前処理法を考慮すると，系内に生成し たメタンスルフィン酸の検出のためには, 定量操作で述 べた多段階操作が必要である。比色定量法と同様に, ジ アゾスルホンの溶解性から考えて, HPLCにおいても 溶媒抽出操作を省くことはできなかった。従って, ここ ではメタンスルフィン酸抽出時のブタノール量, メタン スルフィン酸転溶時の酢酸ナトリウム濃度及びジアゾス ルホン抽出時のクロロホルム量の最適条件を求めた。

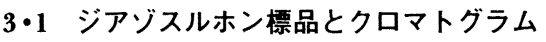

合成したジアゾスルホンは, ${ }^{1} \mathrm{H}-\mathrm{NMR}$ スペクトルに より $95 \%$ 以上の純度を有することを確認した. 又, 本 化合物は, 上記逆相系 HPLC で保持時間 8.1 分に単一 のピークを与えた。

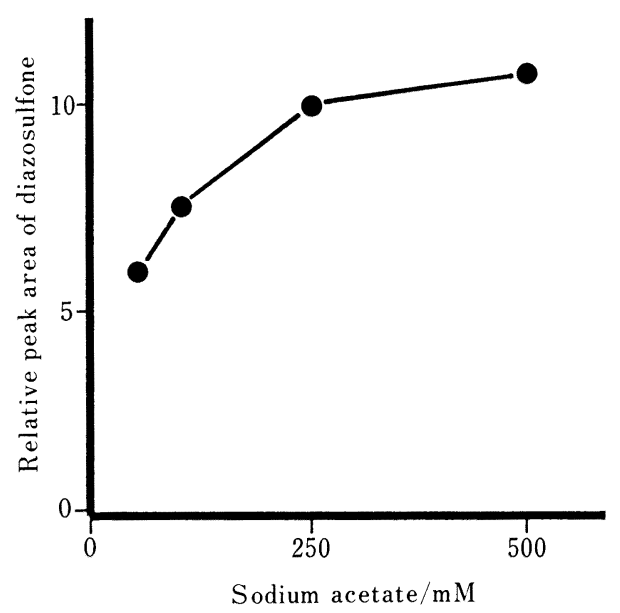

Fig. 3 Effect of the concentration of sodium acetate on the back extraction of the methanesulfinic acid in butanol.

Reaction conditions and HPLC conditions are the same as in Fig. 2.

\section{$3 \cdot 2$ メタンスルフィン酸抽出時のブタノール量}

$1 \mathrm{mM}$ のメタンスルフィン酸ナトリウム水溶液 $0.5 \mathrm{ml}$ を用いて, 抽出に用いる至適ブタノール量を $0.1 \sim 2 \mathrm{ml}$ の容量範冊で検討した (Fig. 2). その結果, ジアゾス ルホンの最大ピーク面積值を示した, $1 \mathrm{ml}$ を用いるこ ととした。

\section{$3 \cdot 3$ メタンスルフィン酸転溶時の酢酸ナトリウム濃} 度

$1 \mathrm{mM}$ のメタンスルフィン酸ナトリウム水溶液 $0.5 \mathrm{ml}$ を用いて, ブタノール抽出後のメタンスルフィン酸転溶 に用いる至適酢酸ナトリウム濃度を 50 ～500 mM の範 囲で検討した（Fig. 3). その結果， $250 \mathrm{mM}$ を超えた ところでジアゾスルホンのピーク面積值はほぼ一定に達 したが，最大值を示した $500 \mathrm{mM}$ を用いることとし た。

\section{$3 \cdot 4$ ジアゾスルホン抽出時のクロロホルム量}

$1 \mathrm{mM}$ のメタンスルフィン酸ナトリウム水溶液 $0.5 \mathrm{ml}$ を用いて, ジアゾスルホン抽出に用いる至適クロロホル ム量を検討した。.Fig. 4 には, クロロホルム $50 \mu \mathrm{l} \sim 2$ $\mathrm{ml}$ の容量範囲で検討した際のジアゾスルホンの相対回 収率を示した。ここでの結果は, 溶媒量を少なくするこ とでジアゾスルホンの濃縮抽出が可能であることを示し ているが，クロロホルム量が $0.1 \mathrm{ml}$ 以下になると回収 


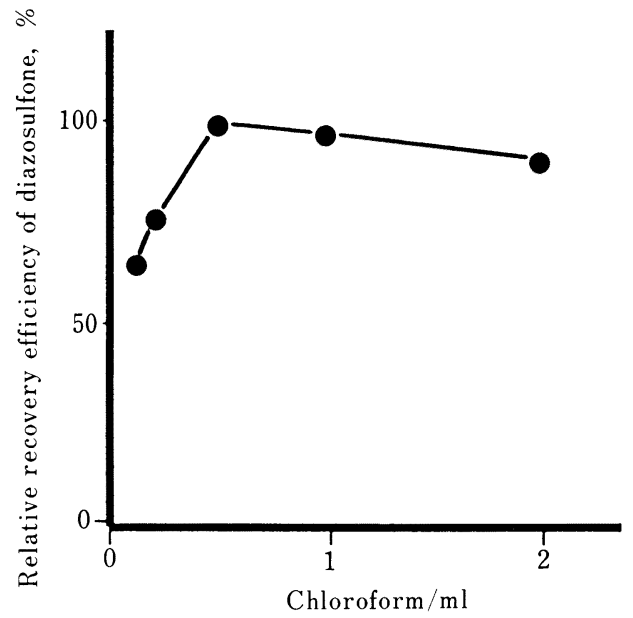

Fig. 4 Effect of the volume of chloroform on the extraction of diazosulfone.

Reaction conditions (except for volume of chloroform) and HPLC conditions are the same as in Fig. 2.

率が約 $65 \%$ まで減少するため, $0.5 \mathrm{ml}$ をクロロホルム の至適容量とした.

\section{$3 \cdot 5$ メタンスルフィン酸の検出下限}

以上の検討結果に基づいて, $1 \mathrm{mM}$ のメタンスルフィ ン酸ナトリウム水溶液 $0.5 \mathrm{ml}$ より生成したジアゾスル ホンのクロロホルム溶液 $(5 \mu \mathrm{l})$ のクロマトグラムを Fig. 5(b) に示した. ジアゾスルホン標品のクロマトグラム からは見られない反応副生物と思われるピークが現れて いるが，定量には影響を与えない。このピーク面積値 と, $1 \mathrm{mM}$ のジアゾスルホン標品から得られるピーク面 積値との比較によって, 一連の前処理を含めたメタンス ルフィン酸からジアゾスルホンの生成収率が約 $92 \%$ で あると算出された.

更に, メタンスルフィン酸ナトリウムの低濃度域にお ける直線性を検討した結果， $0.5 \sim 10 \times 10^{-3} \mathrm{mM}$ の濃度 範囲でピーク面積值との間に直線関係が認められ, 検出 下限濃度は $0.25 \times 10^{-3} \mathrm{mM}(S / N=3)$ であった。

\section{3・6 Fenton 反応における OH ラジカルの検出}

従来から知られてきた次の二つの $\mathrm{OH}$ ラジカル発牛 系に適用し, 発生するラジカルの定量を試みた. 過酸化 水素を発生源亡する Haber-Weiss 反応に基づく OH ラ ジカルの発生系については, 既に多くの報告例があるの で, それに従って OH ラジカルを発生させ, メタンス

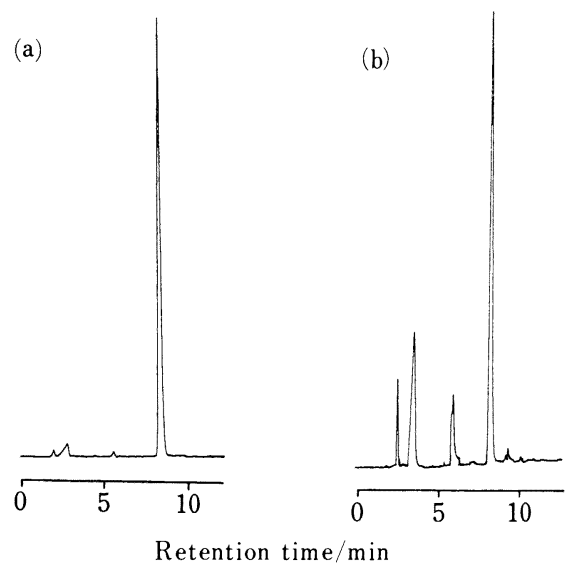

Fig. 5 Chromatograms of the diazosulfone derived from sodium methanesulfinate

(a) diazosufone synthesized, (b) reaction mixture. HPLC conditions are the same as in Fig. 2.

ルフィン酸の生成に基づくジアゾスルホンの検出を試み た.すなわち, 過酸化水素濃度を $1 \mathrm{mM}$ に固定して, 反応に用いる硫酸鉄 $\left(\mathrm{Fe}^{2+}\right)$ の至適濃度を求めたとこ ろ, $4 \mathrm{mM}$ でジアゾスルホンの最大ピーク面積值を示し たので，以下この濃度比に基づいて検討した。

同様の操作により, 過酸化水素の低濃度域における直 線性を検討した結果, $10 \sim 200 \times 10^{-3} \mathrm{mM}$ の濃度範井 において, OH ラジカルの発生により生成したと考えら れるメタンスルフィン酸由来のジアゾスルホンのピーク 面積値との間に良好な直線関係が認められた。

この結果を, 先の 3.5 で得られた結果と共に検量線 として Fig. 6 に示した.この検量線によれば, $80 \times 10^{-3} \mathrm{mM}$ の過酸化水素から $8.8 \times 10^{-3} \mathrm{mM}$ の $\mathrm{OH}$ ラジカルが発生することになるので, Fenton 反応にお ける $\mathrm{OH}$ ラジカル発生率は約 $11 \%$ と算出された。この 值は, 先のチオバルビッール酸法の改良法 ${ }^{8)}$ から得られ た値よりも若干低值ではあるが，その理由については， それが吸光光度法であるということや, 反応に用いる金 属種の違い等が考えられる.この点については, 測定方 法の違いによる直接比較等, 今後更に検討を加えていか なければならない。

\section{$3 \cdot 7$ 過酸化水素の UV 照射における OH ラジカル の検出}

過酸化水素の DMSO 水溶液を用いて, 低濃度域にお ける直線性を検討した結果, $10 \sim 200 \times 10^{-3} \mathrm{mM}$ の濃 


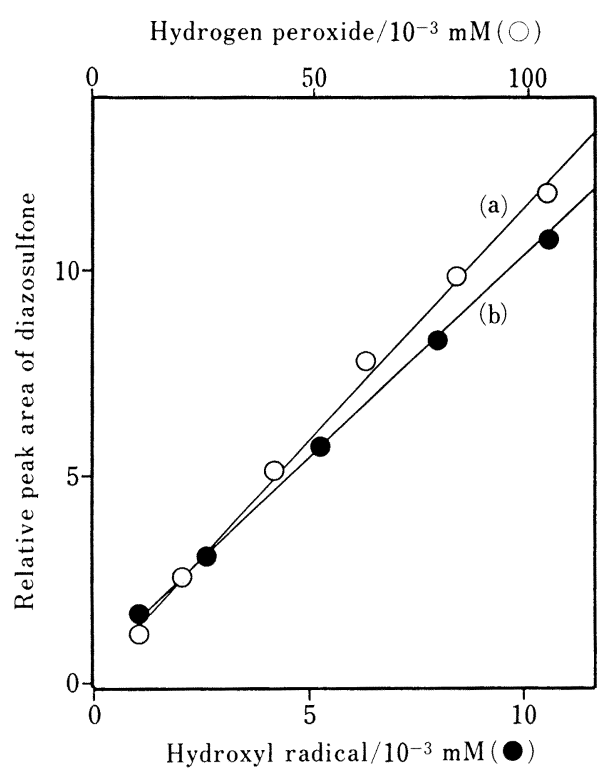

Fig. 6 Calibration curves of hydroxyl radical $(\cdot \mathrm{OH})$ and hydrogen peroxide $\left(\mathrm{H}_{2} \mathrm{O}_{2}\right)$

(a) relationship between $\mathrm{H}_{2} \mathrm{O}_{2}$ concentration and diazosulfone derived from the reaction of DMSO and $\cdot \mathrm{OH}$, (b) relationship between $\cdot \mathrm{OH}$ concentration and diazosulfone derived from sodium methanesulfinate

度範囲において，OH ラジカルの発生により生成したよ 考えられるメタンスルフィン酸由来のジアゾスルホンの ピーク面積値との間に良好な淔線関係が認められた.

この結果を, 先の 3.5 で得られた結果と共に検量線 として示した。この検量線によれば, $80 \times 10^{-3} \mathrm{mM} の$ 過酸化水素から $7.4 \times 10^{-3} \mathrm{mM}$ の $\mathrm{OH}$ ラジカルが発生 することになるので, 過酸化水素-DMSO 水溶液の UV 照射実験における $\mathrm{OH}$ ラジカル発牛率は, 約 $9.2 \%$ と
見積もることができる.

なお，OH ラジカルスカベンジャーとしてよく使われ ているチオ尿素を, 反応系に濃度 $0.5 \sim 5 \mathrm{mM}$ の範囲で 添加した実験では, いずれの系においてもジアゾスルホ ンのクロマトグラム上のピークは観察されず，OH ラジ カルとDMSO との反応が抑制されることが観察され た。

本法は, 操作手順等で比色定量法より優れるものでは ないが，被測定試料が比色定量法に比べて少量ですむば かりではなく，きょう雑成分との分離機能が備わってい る点で優れていると言える. 更に, 感度的には比色定量 法と比べて約 10 倍程度が高いことが分かった。

以上，本研究は多段階に及ぶ前処理を含むため，操作 が煩雑になるが，ジアゾスルホンの HPLC 検出を OH ラジカルの定量に応用した例としては初めての方法であ り, 検出の選択性及び感度が高いことから, 生体試料等 への応用が期待される。

\section{文献}

1）八木國夫，中野 稔監修: “活性酸素”, (1987), (医歯薬出版).

2) 中野 稔, 浅田浩二, 大柳善彦編: “活性酸素”, （1988），(共立出版）.

3) Y. Yoshimura, K. Otsuka, K. Uchiyama, H. Tanaka, K. Tamura, K. Ohsawa, K. Imaeda: Anal. Sci., 5, 161 (1989).

4) 能田 均, 李 明求, 渡邊知仁, 長岡寛明, 大倉洋 甫: 分析化学, 38, 562 (1989).

5) S. M. Klein, G. Cohen, A. I. Cederbaum: Biochemistry, 20, 6006 (1981).

6) M. G. Steiner, C. F. Babbs: Arch. Biochem. Biophys., 274, 478 (1990).

7) C. F. Babbs, M. J. Gale: Anal. Biochem., 163, 67 (1987).

8) 今井 弘, 荒井善一, 中井安雄: 日化, 1993, 1047.

Indirect liquid chromatographic determination of hydroxyl radical based on the production of methanesulfinic acid. Keiji GAMOH and Maki SAKAMOTO (Faculty of Education, Kochi University, 2-5-1, Akebono-cho, Kochi-shi, Kochi 780)

An indirect liquid chromatographic determination method for the hydroxyl radical in an aqueous system was described. The method is based on the production of methanesulfinic acid as the primary product by the reaction of hydroxyl radical with dimethyl sulfoxide. The methanesulfinic acid formed was coupled with diazonium salt to afford the diazosulfone derivative, which was detected and equantified by reversed-phase liquid chromatography at $420 \mathrm{~nm}$. The practical conditions for the methanesulfinic acid detection were optimized. Linearity of the methanesulfinic acid formation was observed in the range from $0.5 \times 10^{-3} \mathrm{mM}$ to $10 \times 10^{-3} \mathrm{mM}$. To evaluate this method for estimat- 
ing hydroxyl radical production, two model systems, including the Fenton reaction and ultraviolet photolysis of hydrogen peroxide were studied. The theoretical maximum yield of hydroxyl radical in the systems could be calculated and compared to the measured dimethyl sulfoxide oxidation. The estimated concentration of hydroxyl radical from $80 \times 10^{-3} \mathrm{mM}$ of hydrogen peroxide in the Fention reaction was $7.4 \times 10^{-3} \mathrm{mM}$. The present method may prove useful for detecting hydroxyl radical involvement in biological samples.

(Received April 1, 1994)

\section{Keyword phrases}

hydroxyl radical; conversion of dimethyl sulfoxide into methanesulfinic acid; diazosulfone formation; reversed-phase HPLC. 